
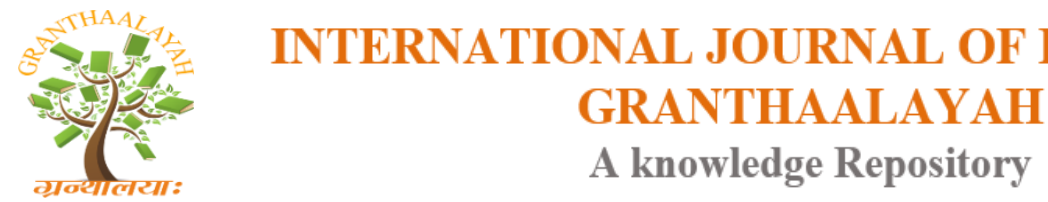

Science

\title{
NATURAL DYES EXTRACTED FROM WASTE LEAVES OF TERMINALIA CATAPPA LOCALLY KNOWN AS TROPICAL ALMOND AND ITS APPLICATION ON SILK FABRICS PRETREATED WITH ECO FRIENDLY AND NONECO-FRIENDLY MORDANTS
}

\author{
Dr.Yogesh Vadwala *1, Dr.Namrita Kola ${ }^{2}$ \\ ${ }^{* 1}$ S.M.Patel College of Home Science, Motabazar, Vallabh Vidyanagar 388120 Gujarat, India \\ ${ }^{2}$ Post Graduate Department of Home Science, Sardar Patel University, Vallabh Vidyanagar \\ 388120 Gujarat, India
}

DOI: https://doi.org/10.29121/granthaalayah.v5.i5.2017.1845

\begin{abstract}
The use of non-toxic and eco-friendly natural dyes on textiles has become a matter of significant importance because of the increased environmental awareness in order to avoid some synthetic dyes. Synthetic dyes are hazardous and carcinogenic and also release vast amount of pollutant in the environment during their manufacture and application, thus revival of natural dyeing techniques as one of the alternative is being emphasized for this purpose. Most effective ways for reducing environmental pollution is the replacement of polluting materials and chemicals by ecofriendly natural materials. Many natural resources which are being wasted indiscriminately or thrown away as a waste product contain useful dyes and pigments. In the present study, natural dye extracted from the waste leaves of Terminalia Catappa (tropical almond) and its application on silk fabrics pretreated with eco-friendly and non-eco-friendly mordants have been carried out successfully. Different shades with excellent to good fastness properties have been obtained.
\end{abstract}

Keywords: Natural Dyes; Terminalia Catappa; Mordant; Dyeing; Eco-Friendly; Fastness.

Cite This Article: Dr.Yogesh Vadwala, and Dr.Namrita Kola. (2017). "NATURAL DYES EXTRACTED FROM WASTE LEAVES OF TERMINALIA CATAPPA LOCALLY KNOWN AS TROPICAL ALMOND AND ITS APPLICATION ON SILK FABRICS PRETREATED WITH ECO FRIENDLY AND NONECO-FRIENDLY MORDANTS." International Journal of Research - Granthaalayah, 5(5), 125-137. 10.29121/granthaalayah.v5.i5.2017.1845.

\section{Introduction}

Natural dyes are known for their use in colouring of food substrate, leather, wood as well as natural fibers like wool, silk, cotton and flax as major areas of application since ancient times. Natural dyes may have a wide range of shades, and can be obtained from various parts of plants including roots, bark, leaves, flowers, and fruit [1]. 
Until the latter half of the $19^{\text {th }}$ century people were using natural dyes [2]for colouring the textile fibre after invention of synthetic dyes, natural dyes are not used because of the advantage of synthetic dye over natural dye in respect of application, colour range, fastness properties, and availability. Some synthetic dyes are hazardous, carcinogenic and also release vast amount of pollutant in the environment during their manufacturing.[3-10]

Synthetic dyes are not good due to their toxic effect; and it creates allergic reaction to skin and also creates pollution. Thus revival of natural dyeing technique as one of the alternative is being emphasized for this purpose. Many natural resources which are being wasted indiscriminately or thrown away as waste product contain useful dye and pigment. Earlier studies have revealed that the waste contain many flavones which can be effectively used as dyes.[11-12]

Recently, a number of commercial dyers and small textile export houses have started looking at the possibilities of using natural dyes for regular basis dyeing and printing of textiles to overcome environmental pollution caused by the synthetic dyes [13]. Natural dyes produce very uncommon, soothing and soft shades as compared to synthetic dyes. On the other hand, synthetic dyes are widely available at an economical price and produce a wide variety of colours; these dyes however produce skin allergy, toxic wastes and other harmfulness to human body. There are a small number of companies that are known to produce natural dyes commercially. For example, de la Robbia, which began in 1992 in Milan, produces water extracts of natural dyes such as weld, chlorophyll, logwood, and cochineal under the Eco-Tex certifying system, and supplies the textile industry. In USA, Allegro Natural Dyes produces natural dyes under the E colour label for textile industry [14]

For successful commercial use of natural dyes, the appropriate and standardized dyeing techniques need to be adopted without scarifying required quality of dyed textiles materials. Therefore, to obtain newer shades with acceptable colour fastness behaviour and reproducible colour yield, appropriate scientific techniques or producers need to be derived from scientific studies on dyeing methods, dyeing process variable, dyeing kinetics and compatibility of selective natural dyes. A need has also been felt to reinvestigate and rebuild the traditional processes of natural dyeing to control each treatment and pre-dyeing process (preparation, mordanting) and dyeing process variables for producing uncommon shades with balanced colour fastness and eco-performing textiles. Production of synthetic dyes is dependent on petrochemical source, and some of synthetic dyes contain toxic or carcinogenic amines which are not ecofriendly [15]. Moreover, the global consumption of textiles is estimated at around 30 million tonnes, which is expected to grow at the rate of $3 \%$ per annum. The colouration of this huge quantity of textiles needs around 700,000 tonnes of dyes which causes release of a vast amount of unused and unfixed synthetic colourants into the environment [16].

Natural dyes serve duel purposes of catering to fashion trends as well as being environment friendly. In this context, India is at an advantageous position since the country holds a rich reservoir of natural resources with potential products. According to recent studies the present Indian flora is estimated to contain about 50,000 species. [17]

In this article, we review the studies carried out so far on the application of natural dyes on silk from waste leaves of Tropical almond (Terminalia catappa). 

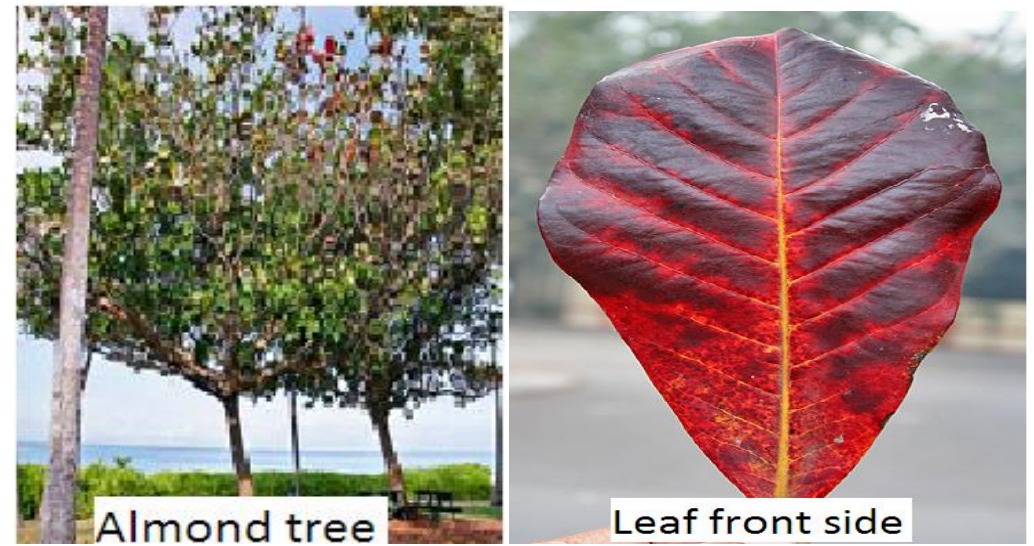

Source of images: Google Images

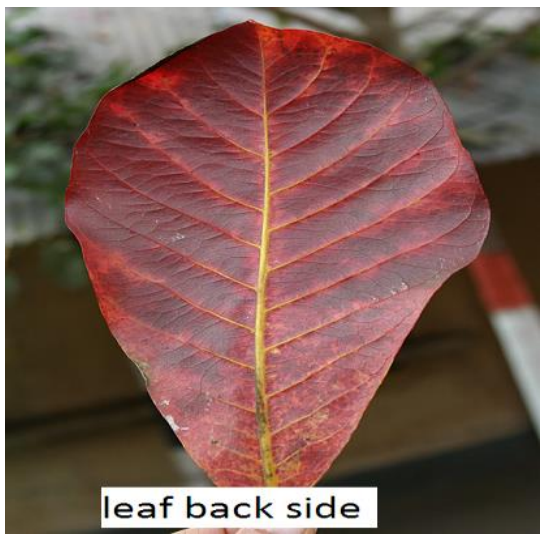

Photograph 1: Tropical almond (Terminalia catappa)

It is a large, spreading tree now distributed throughout the tropics in coastal environments. It grows to about 35 meter tall, with an upright, symmetrical crown and horizontal branches. The tree is tolerant of strong winds, salt spray, and moderately high salinity in the root zone. It grows principally in freely drained, well aerated, sandy soils. The species has traditionally been very important for coastal communities, providing a wide range of non-wood products and services. It is widely planted throughout the tropics, especially along sandy seashores, for shade, ornamental purposes, and edible nuts. During the dry season (autumn), the leaves turn into colours of red, copper, gold. The tree usually sheds all its leaves twice a year in January-February and JulyAugust. The tree first drops its leaves when it reaches 3-4 years old and then every year. see Photograph-1.

The leaves are large, 15-25 centimeters (5.9-9.8 inch) long and 10-14 centimetres (3.9-5.5 inch) broad, ovoid, glossy dark green and leathery. Before falling, they turn pinkish-red or yellowbrown, due to pigments such as violaxanthin, lutein, and zeaxanthin. The leaves contain several flavonoids (like kaempferol or quercetin), several tannins (such as punicalin, punicalagin or tercatin), saponines and phytosterols. Due to this chemical richness, the leaves and also the bark are used in different traditional medicines for liver diseases, dysentery and diarrhea. It is also reported that the leaves contain agents for prevention of cancers (although they have not demonstrated anticarcinogenic properties) and antioxidant as well as anticlastogenic characteristics see figure-1

The leaves are found to have strong anti-bacterial properties and promote fish breeding, curing sick fish and speed up healing of damage. The dried leaves act as a "black water extract" which gradually turns the water brown like tea and effectively reduces the $\mathrm{pH}$ levels in water, releasing organic compounds such as humic acids, flavanoids and tannins into the water which absorb harmful chemicals.[18]

\section{Material and Methods}

Fallen leaves of tropical almond are big in size and easy to collect. Pinkish-reddish leaves were collected and dried at room temperature, ground and sieved. 


\subsection{Extraction of Dye}

100 gram dry powder was taken in 1 litre water and allowed to stand for overnight. Next day the mixture was boiled for 30 minute and then filter with cotton cloth and with simple filter paper to get a clear solution. See Photograph-2 The weight of dry powder after dye extraction was taken to know the concentration of dye by using following formula. $\mathrm{pH}$ of dye solution was measured. (Weight of the dry powder after extraction was 80 grams and $\mathrm{pH}$ of the dye solution was acidic 4-5)

$\begin{aligned} & \text { Total soluble } \\ & \text { matter content }\end{aligned}=\left[\begin{array}{l}\text { Dry wt. of waste } \\ \text { leaves/bark }\end{array}\right]-\left[\begin{array}{l}\text { Dry wt. of insoluble matter } \\ \text { after extraction }\end{array}\right]$

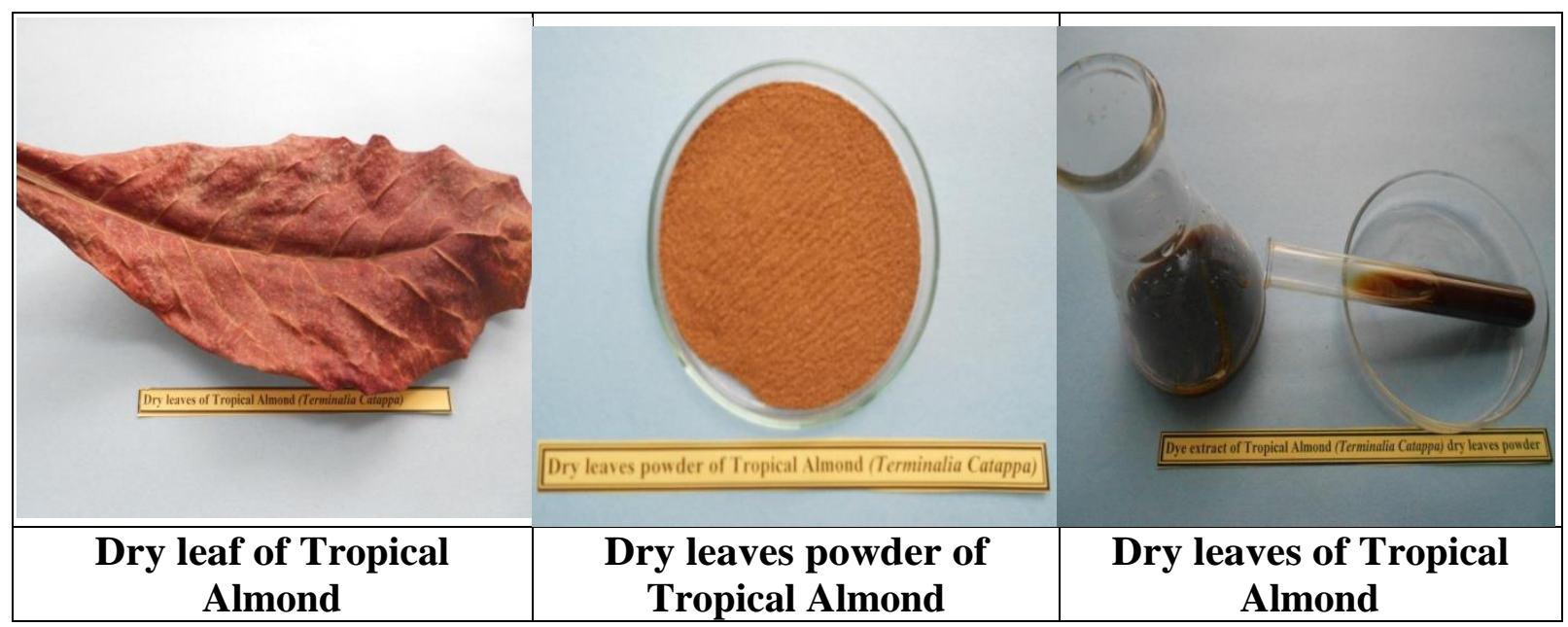

Photograph 2: Dry leaf, dry leaves powder and dye extract of tropical almond

\subsection{Spectral Analysis of Dye Extract}

IR spectra of dye extract were obtained by using-IR Spectrometer Perkin Elmer Spectrum GX Range: $10,000 \mathrm{~cm}-1$ to $370 \mathrm{~cm}-1$; ATR accessory for reflectance measurement; IR Quant software; Spectrum search software. Spectra were recorded in $4000-400 \mathrm{~cm}^{-1}$ by filling the solid dye extract under a form of thin film of potassium bromide $(\mathrm{KBr})$ spectral pellets. see graph-1

UV-VIS absorption spectra of dye extract were obtained by using a LAMBDA 19 UV/VIS/NIR spectrophotometer at Data interval $1.0000 \mathrm{~nm}$, Scan speed $240.00 \mathrm{~nm} / \mathrm{min}$, Slit width 5.0000nm, Smooth band width $8.00 \mathrm{~nm}$ see graph-2

\subsection{Dyeing Procedure}

Silk fabric samples were scoured in mild detergent solution and dried in shade then weighed accurately and further soaked in water and treated with $10 \%$ mordant solution for 30 minutes at room temperature. Mordants used were eco-friendly and non eco-friendly for comparison only as shown in table-1

Dye solution was taken on the weight of fabric for $10 \%$ shade and $\mathrm{M}: \mathrm{L}=1: 30$ was maintained The dye bath was warm to which mordanted fabric sample was entered and the temperature was 
increased up to 45 to $50^{\circ} \mathrm{C}$ ) for $25-30$ minute. The $\mathrm{pH}$ of dye bath was measured. The sample was allowed to cool in the dye bath then washed in cold water, squeezed and dried in shade.

\subsection{Colour Fastness Properties}

Colour fastness properties mainly sunlight, washing, perspiration (acid \& alkali), rubbing (dry \& wet) was carried out using standard methods.[19]

\subsection{Colour Strength}

Colour strength of dyed cotton fabric was measured in terms of L, a, b colour scale by using hunter lab instrument (Hunterlab EasyMatchQC) Colour flex EZ 45/0, Reflectance mode

\section{Result and Discussion}

Terminalia cattappa leaves extract contain several flavonoids, tannins, saponines and phytosterols. Due to this chemical richness leaves extract was used in this study to dye silk.

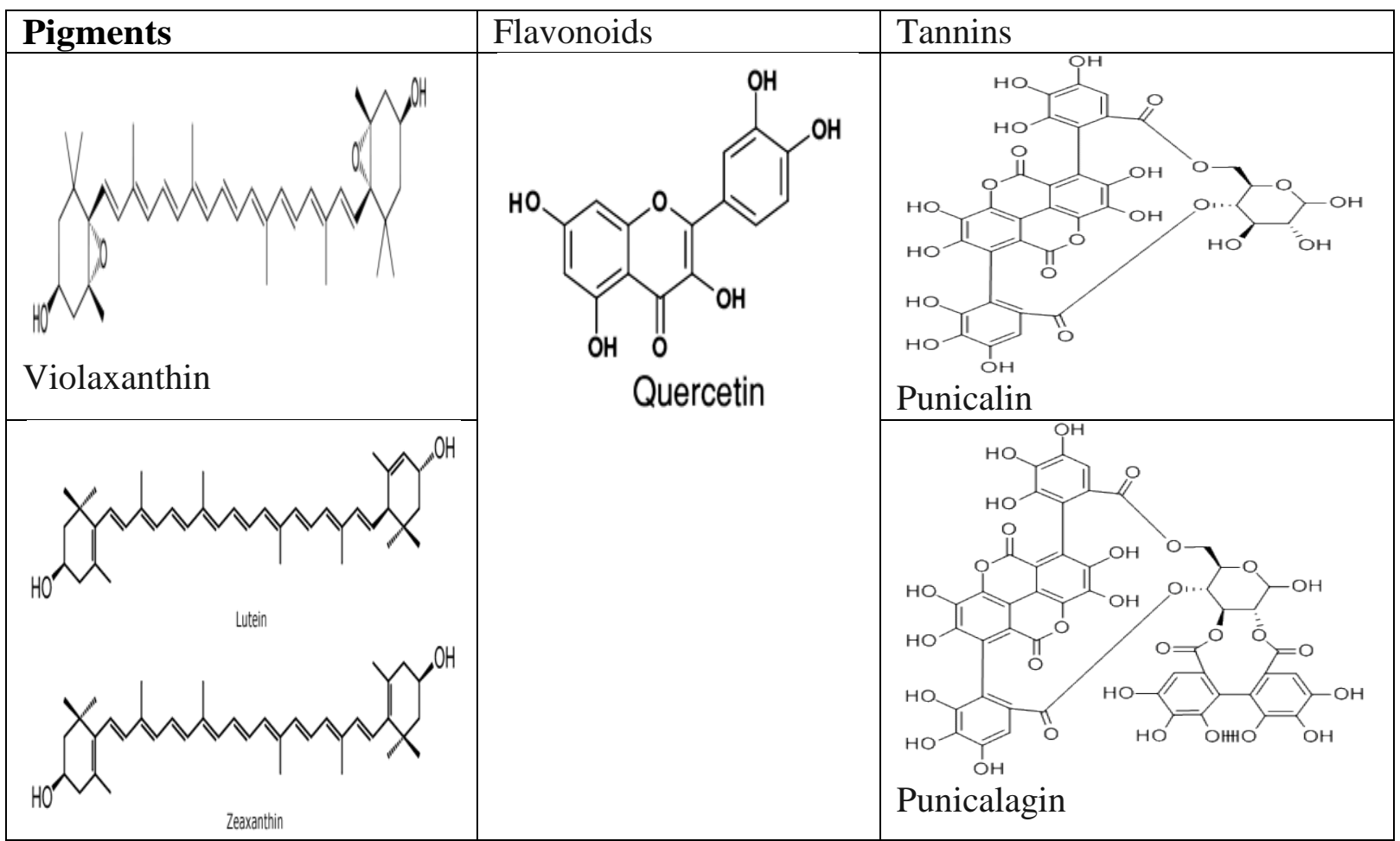

Source of images: Google Images

Figure 1: Structures of pigments, flavonoids and tannins present in leaves of Tropical Almond

\subsection{Characteristics of Tropical Almond Leaves Extract}

The colour was extracted in water photograph 4.1 without using any chemical reagent. $\mathrm{pH}$ of the extract was measured and it was acidic (5.1). Colour of the extract was dark brownish yellow. In order to get exact reproducibility in shade it is important to determine the percentage soluble matter which was calculated and was found to be $2 \%$. 
Characterization of functional group in Tropical Almond leaves extract was recorded with the help of FT- IR spectra in the range of $4000-400 \mathrm{~cm}^{-1}$ by filling the solid dye extract under a form of thin film of $\mathrm{KBr}$ spectral pellets. IR is given in graph 1

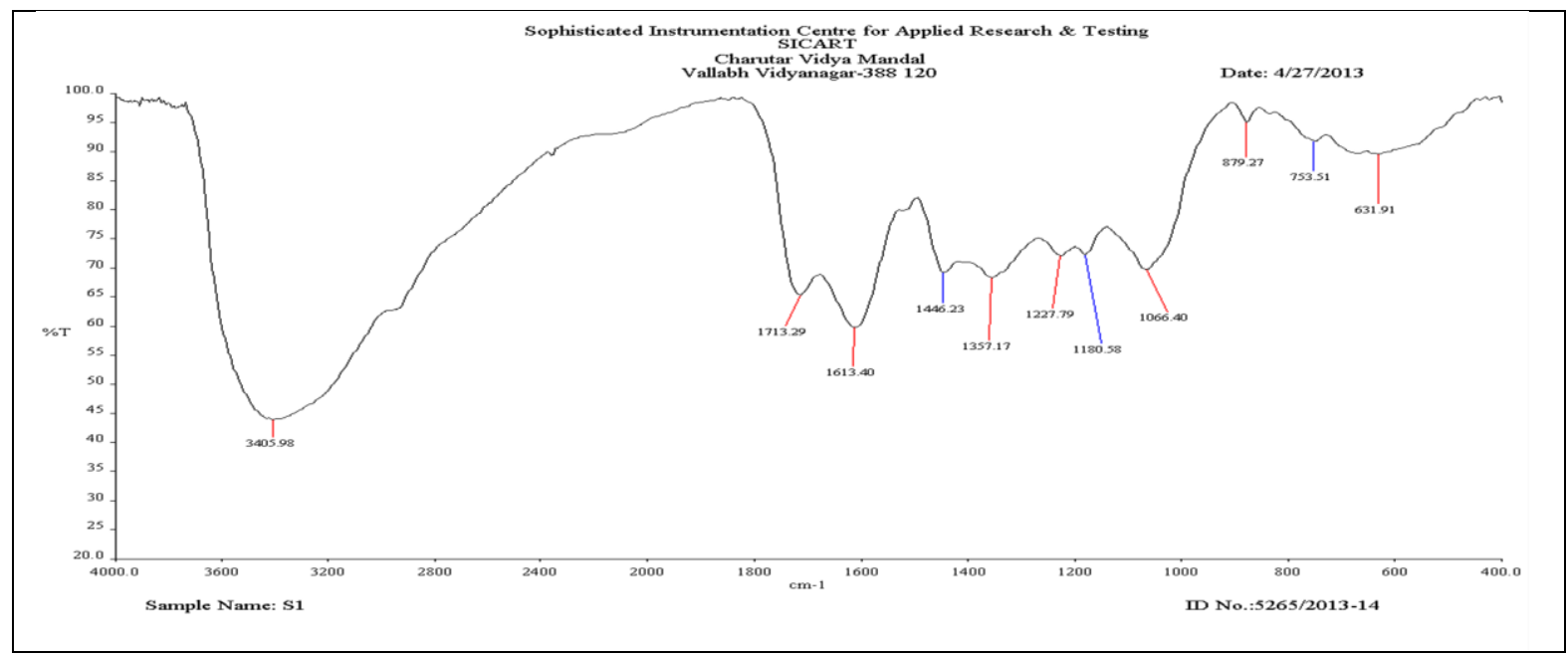

Graph 1: IR of leaves extract Tropical Almond

Table 1: Characterization of functional group in leaves extract of tropical almond

\begin{tabular}{|c|c|c|c|c|}
\hline $\begin{array}{l}\text { Sr. } \\
\text { No. }\end{array}$ & $\begin{array}{c}\text { Absorbency } \\
\text { peak Obtained } \\
\text { in } \mathrm{cm}^{-1}\end{array}$ & Intensity & $\begin{array}{l}\text { Characterization of } \\
\text { Functional Group }\end{array}$ & $\begin{array}{c}\text { Inference } \\
\text { from } \\
\text { IR spectra } \\
\end{array}$ \\
\hline 1 & 3406 & $\begin{array}{l}\text { Strong, broad } \\
(3200-3600)\end{array}$ & O-H stretching & \multirow{11}{*}{$\begin{array}{l}\text { it can be concluded that } \\
\text { there was a quercetin and } \\
\text { related compounds } \\
\text { present in the dye extract } \\
\text { which are known as } \\
\text { flavonoids compound } \\
\text { and most of the yellow } \\
\text { colours are due to } \\
\text { hydroxy and methoxy } \\
\text { derivatives of flavones } \\
\text { and isoflavones [20] }\end{array}$} \\
\hline 3 & 2950 & $\begin{array}{l}\text { Strong } \\
2850-3000\end{array}$ & C-H stretching & \\
\hline 4 & 1713 & Strong & $\mathrm{C}=\mathrm{O}$ stretching & \\
\hline 5 & 1613 & $\begin{array}{l}\text { Variable, medium- } \\
\text { weak, multiple } \\
\text { bands,(1400-1600) }\end{array}$ & $\begin{array}{l}-\mathrm{C}-\mathrm{H} \text { bending, } \quad \mathrm{C}=\mathrm{C} \\
\text { aromatic stretching }\end{array}$ & \\
\hline 6 & 1446 & $\begin{array}{l}\text { Variable, medium- } \\
\text { weak, multiple } \\
\text { bands,(1400-1600) }\end{array}$ & $\begin{array}{l}-\mathrm{C}-\mathrm{H} \text { bending, } \mathrm{C}=\mathrm{C} \\
\text { alkenes and aromatic } \\
\text { stretching }\end{array}$ & \\
\hline 7 & 1357 & $\begin{array}{l}\text { Variable, medium- } \\
\text { weak, multiple } \\
\text { bands,(1400-1600) }\end{array}$ & $\begin{array}{lr}-\mathrm{C}=\mathrm{C} & \text { aromatic } \\
\text { stretching } & \end{array}$ & \\
\hline 8 & 1227 & $\begin{array}{l}\text { medium-weak } \\
(1080-1360)\end{array}$ & C-O stretching & \\
\hline 9 & 1180 & $\begin{array}{l}\text { medium-weak } \\
(1080-1360)\end{array}$ & C-O stretching & \\
\hline 10 & 1066 & $\begin{array}{l}\text { Strong } \quad(1050- \\
1150)\end{array}$ & $\begin{array}{l}\mathrm{C}-\mathrm{O} \text { and } \\
\text { stretching }\end{array}$ & \\
\hline 11 & 879 & Strong (675-1000) & $=\mathrm{CH}$ - bending & \\
\hline 12 & 631 & Strong $(450-650)$ & $\mathrm{C}-\mathrm{O}-\mathrm{H}$ bending & \\
\hline
\end{tabular}


IR spectra showed that $-\mathrm{OH}$ group is in the region of wavelength absorption $3406 \mathrm{~cm}^{-1}$ with a very strong and broad signal. Cluster $\mathrm{C}=\mathrm{C}$ are in the catchment area with a wavelength of $1613 \mathrm{~cm}^{-1}$.In the catchment area $1446 \mathrm{~cm}^{-1}$ indicates the presence ofC $=\mathrm{C}$ of aromatic group and the absorption band 1243-1091 $\mathrm{cm}^{-1}$ indicate the presence of C$\mathrm{O}$ groups, and a catchment area with a wavelength of $807-675 \mathrm{~cm}^{-1}$ indicates a $=\mathrm{CH}$ group.

The Fourier Transform Infra Red (FT-IR) spectra were recorded for isolated samples in the range of $4000-450 \mathrm{~cm}^{-1}$. The pronounced peaks belonging to the vibration of $3366 \mathrm{~cm}^{-1}, 1650 \mathrm{~cm}^{-1}$ and $679 \mathrm{~cm}^{-1}$ in the spectra corresponds to the characterized peaks of flavonoids. [20]The UV absorption specra is given in graph 2

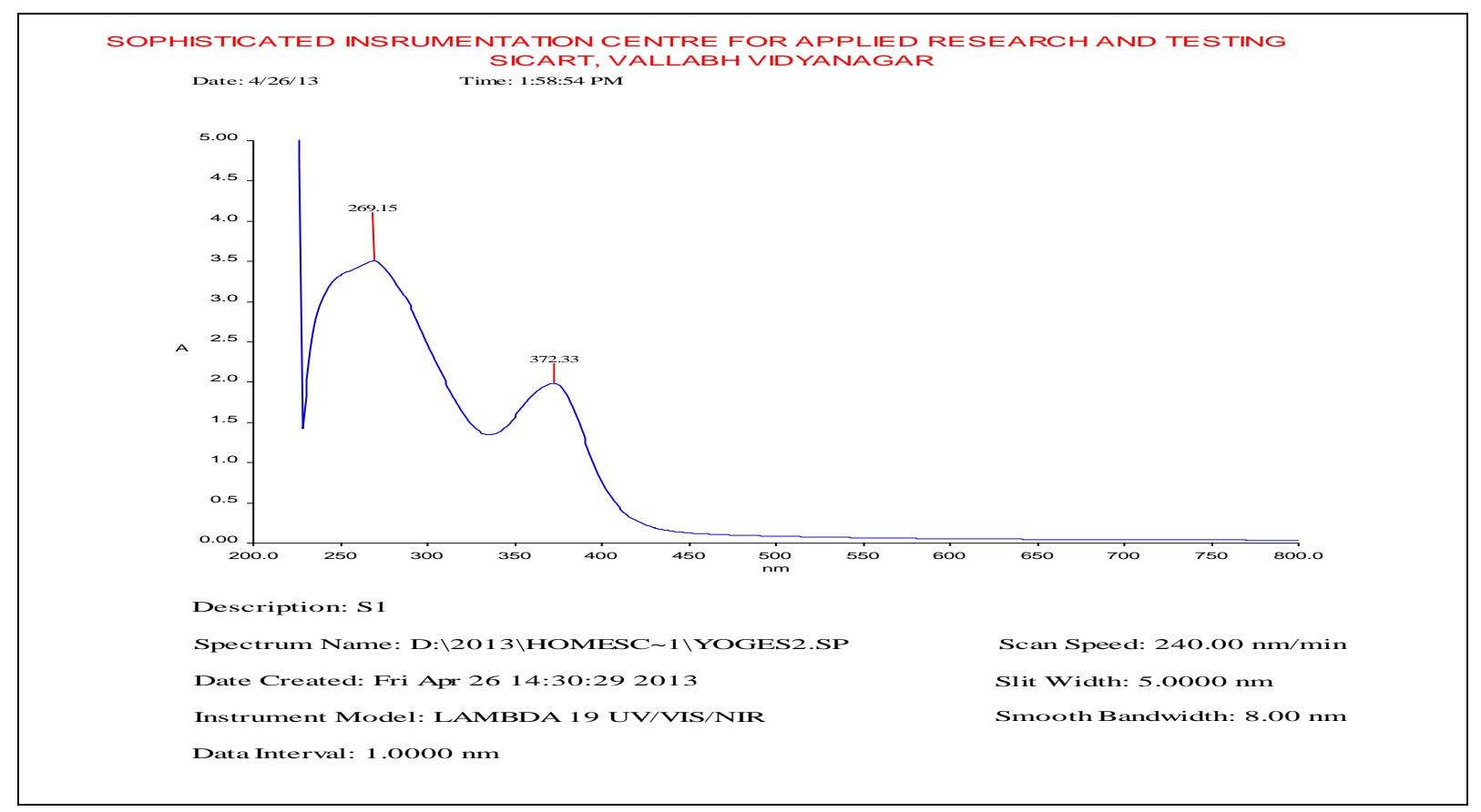

Graph 2: UV of tropical almond leaves extract

UV-Visible spectra for quercetin (spectrum) exhibits two absorption bands at 256 and $374 \mathrm{~nm}$ referring to conjugations. [21]

UV-VIS spectra obtained from dye extracted from Tropical Almond leaves exhibits two absorption bands at 269 and $372 \mathrm{~nm}$ referring to conjugations in the B-ring and A-ring, respectively which is related to quercetin.

From IR and UV data of dye extracted from Tropical Almond leaves it can be stated that there was a quercetin related compound present in the dye extract which has a flavonoid compound and most of the yellow colours are due to hydroxy and methoxy derivatives of flavones and isoflavones.

Experiment was carried out using various eco-friendly mordant and non eco-friendly mordant (for comparison only). $\mathrm{pH}$ of the dye bath was 5-6 without using mordant. By using different mordant (10\%), $\mathrm{pH}$ of the dye bath varied from acidic(1.8) to basic(10.5). (table-2) 
Dyeing of unmordanted fabric, resulted in cream yellow shade. Dyeing with mordanted fabric resulted in different shades of yellow, black and grey which are also shown in plate-4.4.

It was also observed that by using non eco-friendly mordant few shades obtained matched with eco-friendly mordant shades so it is advisable to use more and more eco-friendly mordants.

Plate-4.4 Shade card of silk fabric sample dyed with Tropical Almond leave extract with and without mordants, Colour shade and code number

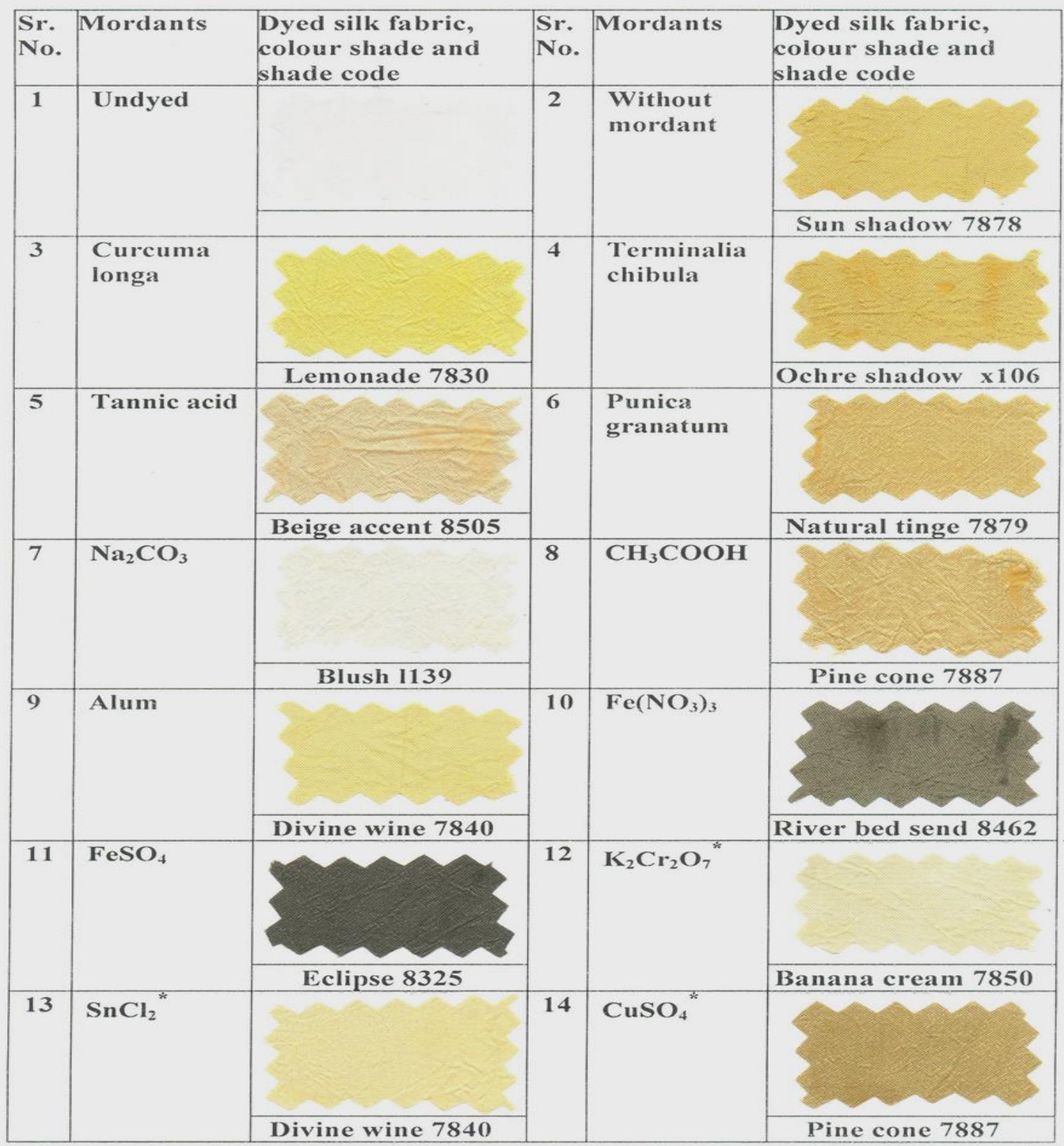

* Non ecofriendly mordants 


\subsection{Colour Shade, Colour Strength and Colour Fastness of Silk Fabric Dyed with Extract of Tropical Almond}

Various colours were obtained which varied from yellow to grey and black, these colours mainly depended on the mordant used. Dyeing of unmordanted silk fabric was resulted in golden yellow shade. Dyeing with mordanted fabric resulted in different shades of yellow, grey and black. The colour shades obtained with ecofriendly mordents was compared with those shades obtained by non eco-friendly mordents. It was found that all shades nearly matched. The shade card is presented in plate 4.4

The presence of mordanted sample in the dye bath influenced the $\mathrm{pH}$ of the dyebath. $\mathrm{pH}$ of the dye bath was 5-6 without mordant. By using various mordant (10\%), $\mathrm{pH}$ of the dye bath varied from acidic(1.8) to basic(10.5). refer table- 2

Table 2: $\mathrm{pH}$ of the dye bath, colour strength and fastness properties of dyed silk fabric with Tropical Almond leaves extract

\begin{tabular}{|c|c|c|c|c|c|c|c|c|c|c|c|c|}
\hline \multirow{2}{*}{$\begin{array}{l}\text { Sr. } \\
\text { No. }\end{array}$} & \multirow{2}{*}{$\begin{array}{l}\text { Name of the } \\
\text { mordant }\end{array}$} & \multirow{2}{*}{$\begin{array}{l}\text { pH } \\
\text { of } \\
\text { dye } \\
\text { bath }\end{array}$} & \multicolumn{3}{|c|}{ Colour strength } & \multicolumn{7}{|c|}{ Fastness properties of dyed fabrics } \\
\hline & & & $\mathbf{L}$ & $\mathbf{a}$ & $\mathbf{b}$ & $\mathbf{L i}$ & $\mathbf{W a}$ & PA & PB & DR & WR & DC \\
\hline 1 & undyed & & 70.57 & 2.22 & -6.35 & & & & & & & \\
\hline 2 & $\begin{array}{l}\text { Without } \\
\text { mordant }\end{array}$ & 5.6 & 58.57 & 0.45 & 22.96 & 5 & $\begin{array}{l}5 \\
\mathrm{~cd}\end{array}$ & 4 & $4-5$ & 5 & 3 & 5 \\
\hline 3 & Curcuma longa & 5.6 & 65.33 & -5.83 & 24.15 & $\begin{array}{l}4 \\
\mathrm{c}\end{array}$ & $\begin{array}{l}5 \\
\mathrm{~cd}\end{array}$ & 5 & $4-5$ & 5 & 4 & 5 \\
\hline 4 & $\begin{array}{l}\text { Terminalia } \\
\text { chibula }\end{array}$ & 4.2 & 55.45 & 2.38 & 22.93 & 5 & 5 & 3 & $3-4$ & 5 & 3 & 5 \\
\hline 5 & Tannic acid & 4.5 & 62.52 & -0.26 & 13.16 & 5 & $\begin{array}{l}5 \\
\mathrm{~cd}\end{array}$ & 5 & 5 & 5 & 3 & 5 \\
\hline 6 & $\begin{array}{l}\text { Punica } \\
\text { Granatum }\end{array}$ & 5.1 & 60.39 & -0.83 & 20.46 & 5 & $\begin{array}{l}5 \\
\mathrm{~cd}\end{array}$ & 5 & 5 & 5 & 3 & 5 \\
\hline 7 & $\mathrm{Na}_{2} \mathrm{CO}_{3}$ & 10.5 & 67.07 & 0.36 & 2.64 & 4 & 4 & $3-4$ & 3 & 5 & 3 & 5 \\
\hline 8 & $\mathrm{CH}_{3} \mathrm{COOH}$ & 3.4 & 58.82 & 0.11 & 18.32 & 5 & $\begin{array}{l}5 \\
\mathrm{~cd}\end{array}$ & 5 & $4-5$ & 5 & 3 & 5 \\
\hline 9 & Alum & 2.8 & 63.87 & -3.90 & 19.71 & 5 & 5 & $4-5$ & 5 & $4-5$ & $2-3$ & 5 \\
\hline 10 & $\mathrm{Fe}\left(\mathrm{NO}_{3}\right)_{3}$ & 1.8 & 40.27 & -0.47 & 6.55 & 5 & $\begin{array}{l}5 \\
\mathrm{~cd}\end{array}$ & 4 & $4-5$ & 5 & 3 & 5 \\
\hline 11 & $\mathrm{FeSO}_{4}$ & 4.0 & 29.09 & 0.13 & 2.77 & 5 & $\begin{array}{l}5 \\
\mathrm{~cd}\end{array}$ & 4 & $4-5$ & 4 & 2 & 5 \\
\hline 12 & $\mathrm{~K}_{2} \mathrm{Cr}_{2} \mathrm{O}_{7}$ & 5.7 & 65.14 & -0.69 & 9.02 & 5 & 5 & $4-5$ & 5 & 4 & 4 & 5 \\
\hline 13 & $\mathrm{SnCl}_{2}$ & 2 & 65.64 & -3.27 & 14.57 & $\begin{array}{l}5 \\
\mathrm{c}\end{array}$ & $\begin{array}{l}5 \\
\mathrm{~cd}\end{array}$ & $4-5$ & 5 & 4 & $3-4$ & 5 \\
\hline 14 & $\mathrm{CuSO} 4$ & 3.5 & 51.91 & 1.32 & 16.73 & 5 & 5 & $4-5$ & 5 & 4 & $2-3$ & 5 \\
\hline
\end{tabular}


Li=Light, Wa=Washing, $\mathbf{P A}=$ Acid Perspiration, $\mathbf{P B}=$ Alkali Perspiration, $D R=D r y$ Rubbing (Dry crocking), WR=Wet Rubbing(Wet crocking), $\mathrm{DC}=$ Dry Cleaning, $\mathrm{c}=$ Colour Change, $\mathrm{cd}=$ Colour Change to Dark

Term for fastness properties except crocking: 5=Excellent, 4=Good, 3=Fair, 2=Poor, 1= Very Poor

Degree of Crocking or staining of fabric: 5= No Staining, 4= Slightly Stain, 3= Noticeably Stain, $2=$ Considerably Stain, $1=$ Heavily Stain

\subsection{Colour Fastness of Silk}

Sunlight fastness property of unmordanted and premordanted fabric sample was studied. Excellent (5) result was obtained for all dyed fabrics. For fabric premordanted with curcuma longa, slight change in colour of the fabric was observed and good to excellent result was obtained.

Washing fastness properties of dyed silk fabric, results were excellent while in case of without mordant, curcuma longa, tannic acid, punica granatum, acetic acid, ferric nitrate, ferrous sulphate and stannous chloride colour of the fabrics changed to dark.

Acid and alkali perspiration fastness properties of unmordanted and mordanted dyed fabric samples were carried out and results obtained for acidic perspiration were good to excellent for all samples. While without mordanted, terminalia chibula and sodium carbonate mordanted dyed fabric was poor to good. For alkaline perspiration the result also obtained was good to excellent, except for dyed sample pre-mordanted with terminalia chibula and sodium carbonate.

The results obtained for dry rubbing fastness was good to excellent for all dyed silk samples. While for wet rubbing fastness it was fair to good except alum, ferrous sulphate and copper sulphate mordanted samples it was poor to fair. Drycleaning fastness properties of dyed silk fabric were good to excellent.

\subsection{L,a,b Colour Scale}

The L,a,b colour scale is more visually uniform than the XYZ colour scale. In a uniform colour scale, the differences between points plotted in the colour space correspond to visual difference between the colour plotted. The $\mathrm{L}, \mathrm{a}, \mathrm{b}$ colour space is organized in cube form. The $\mathrm{L}$ axis runs from top to bottom. The maximum for $\mathrm{L}$ is 100 , which would be a perfect reflecting diffuser. The minimum for $\mathrm{L}$ would be zero which would be black. The $\mathrm{a}$ and $\mathrm{b}$ axis have no specific numerical limits. Positive $a$ is red. Negative $a$ is green. Positive $b$ is yellow. Negative $b$ is blue. Below is a diagram of the hunter L,a,b colour space. Which are also shown in Figure-2. 


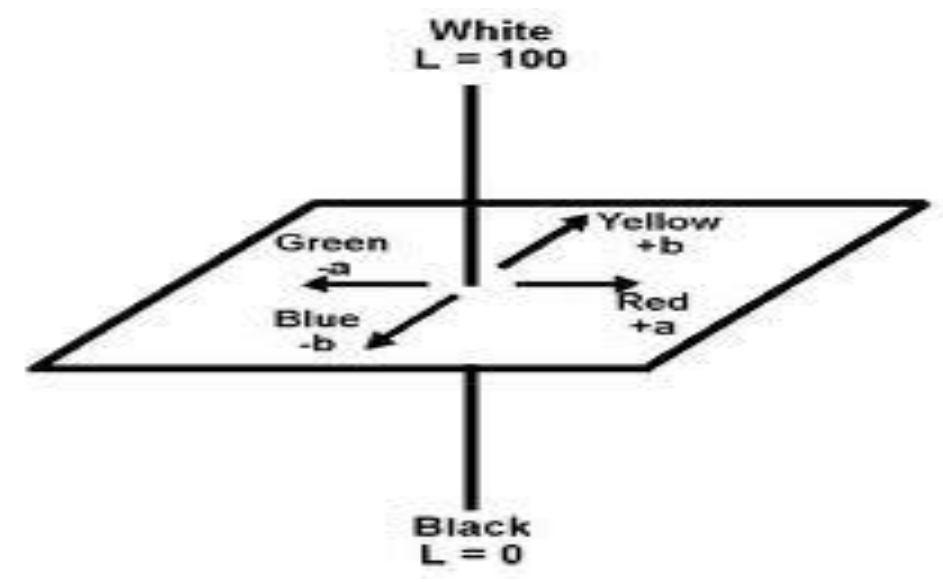

Figure 2: ( L,a,b Colour Scale )

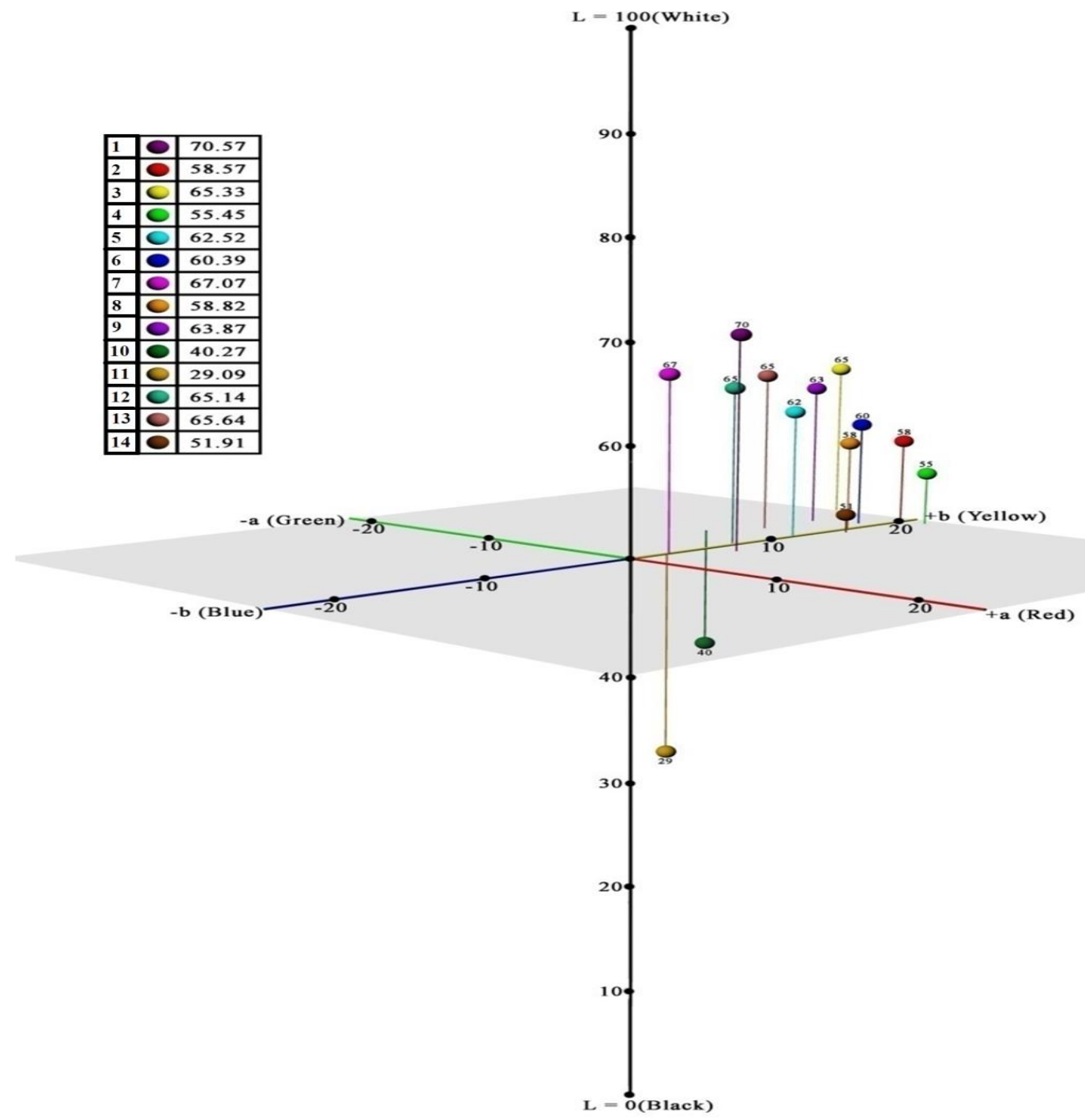

Graph 3: Colour strength of silk fabric dyed with Tropical Almond leave extract 


\subsection{Colour Strength of Silk}

Colour strength of undyed and dyed silk fabric was measured in terms of $\mathrm{L}, \mathrm{a}, \mathrm{b}$ colour scale. The tabulated values are given in table 4.10 and graphically presented in graph 3 . The result was obtained in the range of 51.91 to 67.07 for ' $L$ ' value, except ferrous sulphate and ferric nitrate mordanted fabric shows lower value because of dark colour and for 'a' value it was in the positive range to negative value (1.32 to - 5.83) indicate all the colour value in green region. While in ' $b$ ' the value obtain in the range of 2.64 to 24.15 from the overall data value of L,a,b colour scale shows that colour obtained was yellow $(+b)$, red to green (+a to $-a)$ but near to yellow line. Most of the samples could be classed as greenish yellow or reddish yellow and white $(+\mathrm{L})$ i.e. $\mathrm{L}>50$ except in ferrous sulphate and ferric nitrate mordanted fabric lower value of ' $L$ ' was because of dark colour.

L,a,b value of ecofriendly mordanted silk fabric was compared with L,a,b value of shades obtained by non eco-friendly mordents, Nearly similar L,a,b were obtained by alum and stannous chloride.

\section{Conclusion}

Natural dyes are safe and eco-friendly and textiles dyed with natural dyes are almost free from hazardous chemicals. Red listed mordants may be either avoided or may be optimized as per eco-standard, without impairing the desirable properties (e.g. fastness) of the textiles.

Tropical almond trees are easily found in the local region. Leaves fall twice in a year; these can be collected and used for dyeing variety of colours on cotton very effectively. Different shades on silk fabrics with good to excellent fastness properties have been obtained. After extraction of dye, remaining matter can be use as fertilizer and after dyeing process all the liquid matter can be used in fish breeding. So the process of dyeing is totally eco-friendly.

The present investigation deals with the waste utilization of the natural resources. The commercialization of the present process will be helpful for their viable application in handloom and textile industries. Further, this will also have great impact especially for the economic growth of the rural dyer communities.

\section{References}

[1] Allen, R. L. M. (1971),Colour chemistry,Nelson, London, ISBN 978-0-177-61717-1.

[2] Parkes, C. H. (2002). Creating colour in yarn: an introduction to natural dyes. Knitter's Review (2002-2003).

[3] Nagia, F. A., \& El-Mohamedy, R. S. R. (2007). Dyeing of wool with natural anthraquinone dyes from Fusarium oxysporum. Dyes and pigments, 75(3), 550-555.

[4] Gulrajani M.L. \& Gupta, D. (2001) NCUTE Workshop on dyeing and printing with natural dyes. Indian Institute of Technology, pg, 3-5.

[5] Gulrajani M.L. and Gupta, D., (1999) Conventoin on Natural Dyes, Indian Institute of Technology, Delhi, pp.3-22,

[6] Shanker, R., \& Vankar, P. S. (2007). Dyeing cotton, wool and silk with Hibiscus mutabilis (Gulzuba). Dyes and pigments, 74(2), 464-469. 
[7] Jungalwala F.B., Cama H.R., (1962) Journal of Biochem 85 (1), 1-8.

[8] Patra, S. K., Nanda, B. N., Nayak, A., \& Das, N. B. (2000). Yellow dye from debarked jackfruit wood. COLOURAGE, 47(8), 17-18.

[9] Purohit, A., Das, R., Nayak, A., Nanda, B., \& Das, N. B. (2009). Natural dyes from the waste leaves of Artocarpus heterophyllus. Colourage, 56(5), 89-90.

[10] Chen, P. S., \& Li, J. H. (2006). Chemopreventive effect of punicalagin, a novel tannin component isolated from Terminalia catappa, on H-ras-transformed NIH3T3 cells. Toxicology letters, 163(1), 44-53.

[11] Lin, C. N., Lu, C. M., \& Huang, P. L. (1995). Flavonoids from Artocarpus heterophyllus. Phytochemistry, 39(6), 1447-1451.

[12] Chai-Ming, L., \& Chun-Nan, L. (1994). Flavonoids and docosanoate from Artocarpus heterophyllus. Phytochemistry, 35(3), 781-783

[13] Glover, B., \& Pierce, J. H. (1993). Are natural colorants good for your health? Coloration Technology, 109(1), 5-7.

[14] Hwang, E. K., Lee, Y. H., \& Kim, H. D. (2008). Dyeing, fastness, and deodorizing properties of cotton, silk, and wool fabrics dyed with gardenia, coffee sludge, Cassia tora. L., and pomegranate extracts. Fibers and Polymers, 9(3), 334-340.

[15] K. Hunger; (2003) Industrial dyes. WILEY-VCH verlag Gmbh \& Co. KGaA, Weinheim,Germany p. 569-72.

[16] Samanta, A. K., \& Agarwal, P. (2009). Application of natural dyes on textiles. ,IndianJournal of Fibre \& Textile Research, Vol.34(December 2009)No. 4, pp. 384-399, ISSN 0975-1025.

[17] Dayal, R., \& Dobhal, P. C. (1999). Some useful dye plants-prospects and possibilities. In Proceedings of Convention on Natural Dyes (pp. 83-94).

[18] Thomson, L. A., \& Evans, B. (2006). Terminalia catappa (tropical almond).Species Profiles for Pacific Island Agroforestry, 2, 1-20.

[19] AATCC Technical manual (2010). 85, American Association of Textile Chemists and Colourists,pg.19,22,25,40,86,91,108,366,368 \& 374.

[20] Sampath, M., \& Vasanthi, M. (2013). Isolation, structural elucidation of flavonoids from Polyalthia longifolia (Sonn.) Thawaites and evaluation of antibacterial, antioxidant and anticancer potential. International Journal of Pharmacy and Pharmaceutical Sciences, 5(1), 336-341.

[21] Duan, Y. (2014). Ultraviolet-Visible spectrum characterizations of Quercetin in aqueous ethanol solution with different $\mathrm{pH}$ values. Journal of Chemical \& Pharmaceutical Research, 6(9).

*Corresponding author.

E-mail address: yogeshvadwala@gmail.com 